University of Nebraska - Lincoln

DigitalCommons@University of Nebraska - Lincoln

Sociology Department, Faculty Publications

Sociology, Department of

$12-1976$

\title{
"Origins of Tolerance": Reply to Crockett
}

J. Allen Williams Jr.

University of Nebraska-Lincoln, jwilliams2@unl.edu

Clyde Z. Nunn

Center for Policy Research

Louis St. Peter

lowa State University

Follow this and additional works at: https://digitalcommons.unl.edu/sociologyfacpub

Part of the Sociology Commons

Williams, J. Allen Jr.; Nunn, Clyde Z.; and St. Peter, Louis, "'Origins of Tolerance": Reply to Crockett" (1976). Sociology Department, Faculty Publications. 125.

https://digitalcommons.unl.edu/sociologyfacpub/125

This Article is brought to you for free and open access by the Sociology, Department of at DigitalCommons@University of Nebraska - Lincoln. It has been accepted for inclusion in Sociology Department, Faculty Publications by an authorized administrator of DigitalCommons@University of Nebraska - Lincoln. 


\title{
“Origins of Tolerance" : Reply to Crockett
}

\author{
J. A L LE N WILLI A MS, J R., University of Nebraska-Lincoln \\ C L Y D E Z. N U N N, Center for Policy Research \\ L O U IS S T. PE T E R, Iowa State University
}

Professor Crockett has described portions of our article as "conceptually barren", and the findings are said to represent "serious distortions"' which, if accepted, will lead to "serious misunderstandings." Coming from a respected colleague, these strong words cannot be taken lightly. Nevertheless, after carefully examining his criticisms, we feel they are misplaced. Let us begin our response by briefly restating the purpose and conclusions of our paper.

The paper's objective was to report findings from a study designed to test a thesis central to Samuel Stouffer's theory of tolerance, viz., exposure to social and cultural diversity fosters a greater appreciation of and support for civil liberties. To test this proposition we used Stouffer's scale of Willingness to Tolerate Nonconformists as a measure of the dependent variable and 6 indicators of exposure to diversity as independent variables. We reanalyzed Stouffer's data using multiple classification analysis and then applied the same technique to data from our replication of his study. Contrary to Crockett's assertion, we did not find "statistically significant associations for all relationships except those involving the male-female 'variable'.' Education, region, city size, and gender were found to be associated with tolerance. Exposure to mass media news is not independently associated with tolerance and occupation is associated with tolerance for men, but not for women. On the basis of trends, e.g., educational gains, urbanization, Stouffer believed that an increasingly large proportion of the population would be exposed to diversity. Hence, he proposed a corollary hypothesis that the society would become more tolerant in the years ahead. A comparison of findings from the two studies supports this proposition. We suggested that the observed increase in tolerance has come about partly from changes in the distribution of some of the variables, e.g., there are proportionally more well-educated people now than formerly. Another portion of the increase in tolerance, we believe, may be attributed to changes in the relationship between some of the variables and tolerance, e.g., education may be providing a greater variety of social and cultural stimuli than previously.

The opening criticism refers to our coverage of previous research. We are chastised first for not giving more extensive accounts of the relationship between tolerance and each of the independent variables. The purpose of the paper, however, was not to provide thorough discussions about these associations. As stated, it was to summarize findings from a study designed to test an important general proposition. Despite this, we are told, in effect, that if the paper could not offer a detailed review and examination of each relationship, then it should not have been written. While this issue cannot be resolved empirically, since it rests on a personal value judgment, it can be suggested that if Crockett's dictum were taken seriously few, if any, 
articles would be written or published. Not only did we fail to cite enough research; Crockett also says we cited the wrong research. Robert Jackman, he says, "deals only secondarily with the meaning of the positive relationship between education and tolerance.' It is " an important paper by Mary Jackman'" that should have been referenced. We do not question the relevance of either paper, but it should be mentioned that Robert Jackman uses Stouffer's data and his discussion of the education-tolerance relationship is directed toward the 15 items in Stouffer's scale. Mary Jackman's paper, on the other hand, focuses on authoritarianism and antiSemitism. Furthermore, as our critic points out, her comments are about attitudes measured with an "agree-disagree", format. Stouffer's tolerance scale does not use this format.

The next criticism is that we should have considered the impact of political climate (threat) on tolerance. To support this contention, Crockett demonstrates that perceived threat from Communists is associated with tolerance. In addition, he cites findings from previous research which appear to indicate that tolerance declined during a period of urbanization and a rising level of education. It will be useful to consider these points separately.

As clearly stated in the paper, it was never our intention to explain all of the variation in tolerance. It was pointed out, for example, that Stouffer found a number of variables to be associated with tolerance, but for the purposes of our study " only those variables believed to be indices of exposure to social and cultural diversity have been selected for analysis." This is not to say that the threat-tolerance relationship is unimportant - only that it is irrelevant to the objectives of our study. In an earlier version of our paper we included a measure of political climate which we called "optimism." This particular measure was chosen because the same question had been asked in both studies and because it was significantly associated with perceived threat from 15 different sources. Subsequently, we decided to delete this variable; one of the reasons being that its inclusion had no affect on the relationships pertinent to testing Stouffer's propositions regarding exposure to diversity and tolerance. Crockett is aware of this finding since, as he mentions, he was a co-author of this version of the paper. However, in his criticism he refers more specifically to fear of Communism and implies that the inclusion of this variable would have altered our conclusions. While we believe that a general measure of political climate is preferable, the same negative finding can be illustrated with his example. Table 1 shows the 1954 and 1973 mean tolerance scores for each category of education before and after including perceived threat from Communists. The effects of city size, region, and gender have been statistically controlled. The findings show quite clearly that the degree of perceived threat from Communists does not change the relationship between education and tolerance. The same thing could just as easily be shown with any of the other variables used in our study.

Just as it was not our intention to explain all of the variation in tolerance in 1954 and 1973, neither was it our purpose to explain all of the variation in tolerance between 1954 and 1973. We put it this way in the paper, "Although the change in 
Table 1. TOLERANCE BY EDUCATION BEFORE AND AFTER CONTROLLING FOR PERCEPTION OF COMMUNIST THREAT, 1954 AND 1973

\begin{tabular}{|c|c|c|c|c|}
\hline \multirow[b]{3}{*}{ Education } & \multicolumn{2}{|c|}{1954} & \multicolumn{2}{|c|}{1973} \\
\hline & Adjusted Mean & Tolerance* & Adjusted Mean & Tolerance* \\
\hline & $\begin{array}{l}\text { Before } \\
\text { Controlling } \\
\text { for Percep- } \\
\text { tion of } \\
\text { Communist } \\
\text { Threat }\end{array}$ & $\begin{array}{l}\text { After } \\
\text { Controlling } \\
\text { for Percep- } \\
\text { tion of } \\
\text { Communist } \\
\text { Threat }\end{array}$ & $\begin{array}{l}\text { Before } \\
\text { Controlling } \\
\text { for Percep- } \\
\text { tion of } \\
\text { Communist } \\
\text { Threat }\end{array}$ & $\begin{array}{l}\text { After } \\
\text { Controlling } \\
\text { for Percep- } \\
\text { tion of } \\
\text { Communist } \\
\text { Threat }\end{array}$ \\
\hline College graduates & 3.71 & 3.68 & 4.30 & 4.17 \\
\hline Some college & 3.38 & 3.38 & 4.08 & 4.02 \\
\hline $\begin{array}{l}\text { High school } \\
\text { graduates }\end{array}$ & 2.98 & 2.98 & 3.60 & 3.63 \\
\hline $\begin{array}{l}\text { Some high school } \\
\text { (9-11 years) }\end{array}$ & 2.59 & 2.59 & 3.01 & 3.07 \\
\hline $\begin{array}{r}\text { Grade school } \\
(0-8 \text { years })\end{array}$ & 2.21 & 2.22 & 2.38 & 2.47 \\
\hline & $\begin{array}{l}\mathrm{N}=3,597 \\
\text { Beta }=.33\end{array}$ & $\begin{array}{l}\mathrm{N}=3,597 \\
\text { Beta }=.33\end{array}$ & $\begin{array}{l}\mathrm{N}=3,091 \\
\text { Beta }=.40\end{array}$ & $\begin{array}{l}\mathrm{N}=3,091 \\
\text { Beta }=.35\end{array}$ \\
\hline
\end{tabular}

*The adjusted means are tolerance scores after controlling for region, city size, and gender.

tolerance cannot be attributed solely to these trends, they would appear to have played an important part in fostering a marked increase in tolerance." Once again, this does not mean that political climate cannot affect a change in tolerance. This is discussed in the paper and even our final statement takes this into account, "Barring a major crisis . . tolerance should continue to increase in the future." The two studies cited by Crockett (Glazer and Lipset; Hyman) use findings originally reported by Hyman and Sheatsley. This study, which Stouffer discusses in his second chapter, suggests that tolerance toward Communists and Socialists declined between 1943 and 1954. In our opinion, events during those years, e.g., the development and use of the atom bomb coupled with hostilities between the socalled free and Communist nations, were perceived as a major crisis. Our research findings suggest the political climate in 1973 contained the same high level of perceived threat as in 1954. (Cantril and Roll have reached much the same conclusion regarding the high level of national anxiety in the early 1970s.) Our data indicate that perceived threat from certain sources, e.g., Communists, may have declined, but fear of other sorts of nonconformists, e.g., criminals, appears to have increased. The net result, which is reflected by our general measure, is that the degree and distribution of feeling threatened remained constant. Hence, political climate cannot explain the rise in tolerance during this time. Since Crockett is familiar with this finding as well, we admit to being puzzled by his criticism. 
Perhaps it relates to his skepticism regarding Stouffer's tolerance scale, especially the implied charge that the scale is more sensitive to issues associated with Communism. However, tolerance is associated with perceived threat from a number of different types of nonconformists, e.g., drug users, hippies, juvenile delinquents. Nevertheless, just for fun, let us suppose that the only relevant change in political climate was the decline in the perceived threat from Communism. Based on the 2,904 cases on whom we have complete information, mean tolerance in 1973 was 3.55. Using a procedure described by Duncan, we can estimate what the mean tolerance would have been if the level of threat from Communists had been the same as it was in 1954. By substituting the 1954 fear-of-Communists distribution (i.e., the mean) into the 1973 equation, mean tolerance is reduced to 3.43. Thus, if everything else remained as it was in 1973, this procedure suggests that the decrease in perceived threat from Communists accounts for a 3.4 percent increase in the level of tolerance. Of course, as mentioned, we do not believe that even this small percentage can be attributed to the reduction in fear of Communists since our data suggest that perceived threat from other sources has increased.

Although admitting that Stouffer's tolerance scale was useful for our purpose, Crockett's final criticism is that "it is obviously quite misleading to use it as the sole indicator of political tolerance.' Space limits do not permit a proper response to this remarkable criticism, but a few comments can be made.

To support his argument, Crockett shows that perception of Communist threat is associated with thinking it a bad idea to report suspected Communists to the FBI, among persons scoring high (scores of 4 and 5) on Stouffer's scale. We are unfamiliar with any scale in the social sciences that perfectly measures a complex attitude. Consequently, variation on a single item measuring tolerance after introducing Stouffer's scale as a control was not an unexpected finding. We were a little surprised, however, to see so much variation (even though he did not control for variation within the upper third of the scale and showed us only part of the total distribution). We were surprised, that is, until we looked more closely at the item used to measure tolerance. Crockett asserts that saying it is a bad idea to report suspected Communists to the FBI is a tolerant response. We agree, but there is an equally plausible motivation for giving this answer. Persons responding that it is a bad idea were not questioned further, but, among those saying it is a good idea, 47 percent said they saw some danger in taking this action. The most frequently mentioned danger (given by 71 percent) was fear of being harmed by Communists. If this many of those saying it is a good idea expressed this fear, it seems likely that many of those saying it is a bad idea must have had the same concern. Another piece of evidence supports this interpretation. It can be seen from the information presented in Table 2 that reporting suspected Communists is curvilinearly associated with education. If education is positively associated with tolerance, as Crockett admits, why would those with the least education rival college graduates as the most tolerant using this item? We think the answer is that they are not giving a tolerant response by saying it is a bad idea to report suspected Communists. They are answering this way out of fear of reprisal. 
Table 2. DISPOSITIONTO REPORT SUSPECTED COMMUNISTS TO THE FBI BY EDUCATION, 1973

\begin{tabular}{|c|c|}
\hline Education & $\begin{array}{l}\text { Adjusted Percent Saying It's a } \\
\text { Bad Idea to Report Suspected } \\
\text { Communists to the FBI* }\end{array}$ \\
\hline College graduates & 63 \\
\hline Some college & 53 \\
\hline $\begin{array}{l}\text { High school } \\
\text { graduates }\end{array}$ & 44 \\
\hline $\begin{array}{l}\text { Some high school } \\
\text { (9-11 years) }\end{array}$ & 41 \\
\hline $\begin{array}{l}\text { Grade school } \\
\text { (0-8 years) }\end{array}$ & $\begin{array}{l}61 \\
\mathrm{~N}=3,546\end{array}$ \\
\hline
\end{tabular}

Crockett also argues that our use of Stouffer's scale is misleading because it correlates only moderately with other measures of tolerance. Additionally, he says that the finding that these items and the scale yield only one factor in a factor analysis "supplies no basis per se for using the tolerance scale as though it were an adequate, exclusive measure of political tolerance." He does not say why with respect to either of these comments. However, let us begin by pointing out that at no place in the paper do we argue for the exclusive use of Stouffer's scale as a measure of tolerance. In fact, we would not recommend its use for other than comparative purposes. The dilemma we faced is a familiar one to sociologists: Do we construct a new scale or stick with the original measure and maintain comparability? Since we wished to test a theoretical proposition using data collected at two points in time, the latter option seemed by far the more preferable. This choice would be feasible, however, only if the scale was reliable and valid. Our analysis indicated that this was a reasonable assumption. The scale, both for 1954 and 1973, meets acceptable standards for reproducibility, minimum marginal reproducibility, and scalability. Concurrent validity, along with the generalizability, of the scale is shown by it being significantly and independently associated with seven items, each of which measures tolerance toward a different type of nonconformist behavior. It is true that the items correlate moderately (.31 to .41) with the scale, but adjusted-item with total-score correlations of this magnitude would be considered very acceptable for items to be included in the scale itself (e.g., see Nunnally, Chapter 8). Furthermore, we do not see what would be gained by including single-item measures of tolerance in the paper as Crockett recommends. Individually or in combination the items show substantially the same thing and do not alter the conclusions. It is generally recognized that a scale is a more efficient method of measuring an 
underlying characteristic, e.g., tolerance, than are individual items. As mentioned, as an additional test of the scale's validity, it was included along with 7 individual items in a factor analysis. Only one factor emerged. We realize this does not prove the scale is measuring a single attitude (a functional unity), any more than a high coefficient of reproducibility proves a scale is unidimensional. However, this finding most certainly supports such a conclusion. Finally, it should be mentioned that the study itself provides construct validation of the scale. Had education not been positively associated with tolerance (as is true for the item chosen by Crockett to measure tolerance), for example, then the validity of Stouffer's scale would have been open to serious question indeed.

In his concluding comment, Crockett expresses the hope that he has alerted social scientists to the "serious misunderstandings of political tolerance", which he perceives in our paper. We, in turn, hope that our response has dispelled the doubts which his comments may have aroused. New evidence may show that our interpretation of the origins of tolerance is wrong. However, we do not find this evidence in Crockett's paper. Thus, at this time we continue to believe that the findings and our interpretation of them are correct.

\section{REFERENCES}

Cantril, Albert H., and Charles W. Roll, Jr. 1971. Hopes and Fears of the American People. New York: Universe.

Duncan, O. D. 1969. "Inheritance of Poverty or Inheritance of Race?" In Daniel P. Moynihan (ed.), On Understanding Poverty. New York: Basic Books.

Glazer, N., and S. M. Lipset. 1955. "The Polls on Communism and Conformity." In Daniel Bell (ed.), The New American Right. New York: Criterion.

Hyman, H. H. 1964. " England and America: Climates of Tolerance and Intolerance (1962)." In Daniel Bell (ed.), The Radical Right. New York: Doubleday.

Hyman, H. H., and P. B. Sheatsley. 1953. "Trends in Public Opinion on Civil Liberties." The Journal of Social Issues 9(3):6-16.

Jackman, M. 1973. "Education and Prejudice or Education and Response-Set?'” American Sociological Review 38(June):327-39.

Jackman, R. 1972. "Political Elites, Mass Publics, and Support for Democratic Principles." Journal of Politics 34(August):753-73.

Nunnally, Jum C. 1967. Psychometric Theory. New York: McGraw-Hill.

Stouffer, Samuel A. 1955. Communism, Conformity, and Civil Liberties. New York: Doubleday.

Williams, J., Jr., C. Z. Nunn, and L. St. Peter. 1976. “'Origins of Tolerance:Findings from a Replication of Stouffer's Communism, Conformity, and Civil Liberties.' Social Forces 55(December):394-408. 